\title{
KONSELING MULTIKULTURAL: UPAYA PREVENTIF BULLYING PADA LESBIAN DI MASYARAKAT DAN SEKOLAH
}

\author{
${ }^{1}$ Nurintan Muliani Harahap, ${ }^{2}$ Amril Maryolo \\ ${ }^{12}$ Universitas Islam Negeri Sunan Kalijaga Yogyakarta \\ E-mail: 1nurintanmuliani53@gmail.com, 2amril600@gmail.com
}

\begin{abstract}
The objectives achieved in this paper are to neutralize cases of bullying that occur in minority groups, especially lesbians in communities and schools using multicultural counseling. In general, people consider lesbians as sinners, sexual deviations and sexual disorders, not infrequently these groups experience discrimination and stigma. The problem faced by this sexual orientation or gender identity requires empathy and sensitivity so that problems can be solved. One of the problems experienced by LGBT especially lesbians is bullying. Forms of intimidation from the nearest person or from others, logging, the exclusion of his friends commonly referred to as bullying behavior. In order for such cases to be unsustainable there needs to be a handling so that minority groups can move in accordance with their respective potential.
\end{abstract}

Keywords: Multicultural Counseling, Lesbian, Bullying

\begin{abstract}
Abstrak
Tujuan yang dicapai dalam penulisan ini adalah untuk menetralisir kasus bullying yang terjadi pada kelompok minoritas khususnya lesbian di masyarakat dan sekolah dengan menggunakan konseling multikultural. Pada umumnya masyarakat menganggap lesbian sebagai pendosa, penyimpangan seksual dan kelainan seksual, tidakjarang kelompok ini mengalami diskriminasi dan stigma. Persoalan yang dihadapi karena orientasi seksual atau identitas gendernya ini memerlukan empati dan kepekaan agar persoalan demi persoalan yang dihadapi dapat teratasi. Salah satu masalah yang dialami oleh LGBT khususnya lesbian adalah bullying. Bentuk intimidasi dari orang terdekat ataupun dari orang lain, pemalakan, pengucilan diri dari temannya yang biasa disebut dengan perilaku bullying. Agar kasus seperti ini tidak berkelanjutan perlu adanya penanganan agar kelompok minoritas dapat bergerak sesuai dengan potensinya masing-masing.
\end{abstract}

Kata Kunci,: Konseling Multikultural, Lesbian, Bullying

\section{PENDAHULUAN}

LGBT merupakan singkatan dari Lesbian, Gay, Biseksual, dan Transgender. Sebagai bagian dari ragam orientasi seksual dan identitas gender. Keberadaan LGBT hingga saat ini masih menjadi masalah secara sosial, teologis dan psikologis. Sehingga pada beberapa hal mereka mendapat perlakuan yang tidak baik. Anarkhisme dan pelecehan tidak pernah luput 


\section{8 | Nurinta Muliani Harahap, Amril Maryolo. AR}

dalam kehidupan mereka. Secara psikologis, orang yang mendapat perlakuan tidak baik akan mengalami dampak-dampak pada aspek kepribadiannya dan kesehatan mentalnya. Seperti trauma, penerimaan rendah, rasa minder dan kecemasan yang jika tidak ditangani secara baik akan semakin memperburuk keadaannya. LGBT juga tidak terlepas dari kekerasan fisik yang mereka alami di masyarakat, keluarga, hingga perlakuan dari pasangan mereka sendiri.

LGBT ini dianggap oleh sebagian masyarakat sebagai pendosa, penyimpangan seksual dan kelainan seksual tidak jarang kelompok ini mengalami diskriminasi dan stigma. Persoalan yang dihadapi karena orientasi seksual atau identitas gendernya ini memerlukan empati dan kepekaan agar persoalan demi persoalan yang dihadapi dapat teratasi.

Salah satu masalah yang dialami oleh LGBT khususnya lesbian adalah bullying. Bentuk intimidasi dari orang terdekat ataupun dari orang lain, pemalakan, pengucilan diri dari temannya yang biasa disebut dengan perilaku bullying. Perilaku bullying akan mempengaruhi psikis kedua belah pihak, baik pelaku bullying maupun korban bullying. Namun dampak yang besar akan dialami oleh korban bullying. Hal tersebut karena posisi yang lemah (inferior) sehingga korban tidak memiliki kemampuan untuk memberikan perlawanan terhadap pelaku yang superior.

Bullying merupakan sebuah kata dari Bahasa Inggris. Bullying terdiri dari satu kata dasar, yaitu kata bully yang artinya penggertak, orang yang mengganggu orang yang lemah. Dalam Kamus Besar Bahasa Indonesia (KBBI) sering dipakai untuk menggambarkan dan menjelaskan fenomena bullying, seperti penindasan, pengucilan, pemalakan, atau intimidasi.

Selain itu, Semai Jiwa Amini (SEJIWA) Foundation juga mengartikan bullying sebagai tindakan penggunaan kekuasaan atau kekuatan untuk menyakiti seseorang atau kelompok orang sehingga korban merasa tertekan, trauma, dan tak berdaya. ${ }^{1}$ Adapun bentuk bullying ialah:

Menurut Wiyani dalam Gerda Akbar, ${ }^{2}$ terdapat empat bentuk bullying, yaitu:

a. Lisan, misalnya memberi julukan, menggoda, mengejek, menghina, mengancam.

b. Fisik, misalnya memukul, menendang, menyelengkat

${ }^{1}$ Yayasan Semai JIwa Amini (Sejiwa) Foundation, "Penelitian mengenai Kekerasan di Sekolah,", hlm. 3

${ }^{2}$ Akbar Gerda, "Mental Imagery Mengenai Lingkungan Sosial Baru Pada Korban Bullying", Journal: FIisip-Ummul, Tahun 2013, 27. 
c. Sosial, misalnya mengabaikan, tidak mengajak berteman, dan memberi isyarat yang tidak sopan.

d. Psikologis, misalnya menyebarkan desus-desus, pandangan yang menunjukkan rasa tidak senang, kebencian, atau kemarahan, menyembunyikan atau merusak barang, pesan jahat lewat SMS dan email, penggunaan ponsel kamera yang tidak patut.

Muncul wacana pro-kontra dalam memandang lesbian. Ada yang melihatnya sebagai pilihan atas hak hidup. Namun ada juga yang melihatnya sebagai perilaku yang deviant dan tidak bermoral. Sikap negatif terhadap kaum lesbian ini melahirkan aturan-aturan yang dapat menghukum kaum lesbian. Prasangka dan Diskriminasi terhadap kaum lesbian ini makin menyebar. Sebuah survei di Amerika Serikat oleh Levitt dan Klasen (dikutip dalam Sarwono dan Meinarno, 2009) menunjukkan bahwa mayoritas orang memiliki kepercayaan bahwa lesbian adalah penyakit dan perlu untuk dilarang secara legal. Bahkan dalam penelitian Henry (dikutip dalam Sarwono dan Meinarno, 2009) ditemukan hanya 39\% orang yang mau mengunjungi praktik dokter seorang homoseksual.

Agar kasus bullying pada kelompok minoritas khusunya lesbian dapat terminimalisir dan tidak berkelanjutan, maka perlu ada penanganan untuk menyelesaikannya. Agar kelompok minoritas lesbian mendapat haknya untuk hidup dengan nyaman ditengah masyarakat sebagai layakanya kelompok mayoritas. Maka penulis disini ingin mendeskripsikan desain penyelesaian kasus bullying pada lesbian secara teoritik.

\section{WACANA LESBIAN DALAM SEKSUALITAS}

Lesbian berasal dari kata lesbos yaitu pulau ditengah lautan Egeis yang pada zaman kuno dihuni oleh para wanita. ${ }^{3}$ Pada dasarnya kata Gay bisa berlaku untuk semua jenis kelamin, baik laki-laki maupun perempuan. Namun pada dewasa ini wanita lebih menyukai penggunaan istilah lesbian. ${ }^{4}$ Contohnya adalah seorang perempuan bermain seks dengan perempuan.

Banyak yang mengatakan bahwa, cinta lesbian sangat mendalam dan lebih hebat dari percintaan orang normal. Dalam permainan senggama merekapun lebih hebat-ganas dibanding pasangan gay. Hal ini dikarenakan elemen erotic dan nafsu yang bergelora pada lesbian itu lebih intens. Kemunculan lesbian bisa dikarenakan oleh: wanita yang bersangkutan terlalu mudah jenuh dalam berhubungan senggama dengan suami atau laki-laki serta ia tidak pernah merasakan orgasme. Faktor traumatis berkaitan dengan

${ }^{3}$ Kartini Kiartono, Psikologi Wanita jilid I, (Bandung: Alumni 1977), 263.

4Sinyo, Anakku Bertanya Tentang LGBT, (Jakarta: PT Elex Media Komputindo, 2014 ), 6. 
pengalaman mendapatkan perlakuan kasar dari laki-laki. Pelarian karena ketidakbahagiaan hidup dan kekecewaan, sehingga mencari sesuatu yang baru dalam hidupnya. ${ }^{5}$

Wacana tentang lesbian selama kurun wakyu tiga dekade ini memiliki pokok pembahasan sentral dalam teori lesbian yaitu identitas, seksualitas dan komunitas adalah pendefinisian lesbian atau lesbianism dalam hubungannya dengan berbagai identitas, kelompok atau gerakan lain. ${ }^{6}$ Pada tahun 1970-an, aktifis feminis lesbian beranggapan bahwa orientasi seksual didasarkan pada aspek biologis. ${ }^{7}$

Kekerasan psikis yang dialami lesbian berupa bullying terutama pada lesbian ekspresi gender buth. Mereka biasanya mendapat perlakuan tidak baik dengan lontaran kata-kata ejekan dan seringnya dilakukan oleh temannya yang laki-laki atau tetangga rumah dengan sindiran atau dengan pandangan mata awas seolah memandang rendah pada lesbian.

\section{LGBT DALAM PANDANGAN HAM DAN HUKUM DI INDONESIA}

Penelitian yang dilakukan oleh Arus Pelangi pada Tahun 2013 menunjukkan bahwa 89,3\% kaum LGBT di Indonesia pernah mengalami kekerasan karena identitas seksualnya. 79,1\% responden menyatakan pernah mengalami bentuk bentuk kekerasan psikis. $46,3 \%$ responden menyatakan pernah mengalami kekerasan fisik. 26,3\% kekerasan ekonomi. 45,1\% kekerasan seksual. 63,3\% kekerasan budaya (Arus Pelangi, 2014). Bahkan kekerasan yang dialami sudah diterima pada saat usia sekolah dalam bentuk bullying. 17,3\% kaum LGBT pernah mencoba untuk bunuh diri, dan 16,4\% bahkan pernah melakukan percobaan bunuh diri lebih dari sekali. Dalam kondisi tersebut, tidak ada regulasi dan peraturan yang dibuat oleh negara yang secara ramah terhadap kaum minoritas LGBT. ${ }^{8}$

Di Indonesia masih ada beberapa produk hukum di tingkat nasional maupun daerah yang mendiskriminasikan kelompok LGBT. Beberapa produk yang diskriminatif itu seperti Peraturan Daerah Provinsi Sumatera Selatan No. 13 Tahun 2001 Tentang Pemberantasan Maksiat di Provinsi Sumatera Selatan. Peraturan Daerah ini mengkriminalisasikan kelompok LGBT dengan

${ }^{5}$ Marzuki Umar Sa'abah, Prilaku Seks Menyimpang Dan Seksualitas Kontemporer Umat Islam. (Yogyakarta: UII press, 2001), 130-131. 2009)

${ }^{6} J a c k s o n$, dkk, Pengantar Teori-teori Feminis Kontemporer, (Yogyakarta: Jalansutra,

${ }^{7}$ Jeffreys, Sheila, The Lesbian Heresy, (Melbourn: Spinifex Press, 1993), 59.

${ }^{8} J$ Jeanete Ophilia Papilaya, "Lesbian, Gay, Biseksual, Transgender (LGBT) dan Keadilan Sosia", Jurnal Humaniora Yayasan Bina Dharma, Vol. III, No. 1, 2016., 28. 
mengkategorikan LGBT sebagai perbuatan pelacuran. Selain itu, Peraturan Daerah Kota Palembang No. 2 Tahun 2004 Tentang Pemberantasan Pelacuran. Peraturan Daerah ini mengkriminalisasikan kelompok LGBT dengan mengkategorikan kelompok LGBT sebagai bagian dari perbuatan pelacuran. Dari beberapa produk hukum tersebut yang bersifat diskriminatif terhadap kaum LGBT yang mengatur aktivitas seksual mereka. Namun yang perlu diketahui, dengan adanya produk-produk hukum yang diskriminatif tersebut dapat berdampak pada masyarakat Indonesia yang masih banyak sekali belum memahami hak asasi manusia dengan baik, belum memahami secara mendalam perihal identitas gender dan orientasi seksual kaum LGBT.

Pancasila sebagai dasar Negara Indonesia, pada sila ke - 5 menyatakan bahwa "Keadilan sosial bagi seluruh rakyat Indonesia". Hal ini merupakan jaminan bahwa negara menjamin keadilan sosial bagi semua rakyat dan melaksanakan hak asasi kepada semua rakyat tanpa terkecuali. Selain itu, pengakuan hak asasi manusia juga telah disahkan dengan Undang-Undang Republik Indonesia Nomor 39 Tahun 1999 tentang Hak Asasi Manusia. Namun demikian, masih saja kaum LGBT yang notabene adalah rakyat Indonesia belum mendapatkan hak asasi yang layak mereka dapatkan seperti hak atas kesetaraan dan non diskrimnasi, hak untuk hidup, hak atas keamanan, hak atas privasi, hak untuk mendapatkan perlakuan manusiawi, hak atas pendidikan, dan hak untuk bekerja. Terbukti banyaknya kasus kekerasan dan diskriminasi yang menimpa kaum LGBT. Pelaku kekerasan dan diskriminasi itu oleh keluarga, masyarakat, dan aparatur pemerintah yang seharusnya melindungi hak-hak warganegaranya.

Perkembangannya, HAM menjadi tren global yang menempati posisi penting perihal pola hubungan antara individu dengan masyarakat dunia. Munculnya HAM tak terlepas dari pergolakan manusia modern yang selalu menghadapi pengaturan negara dan semakin meningkatnya kesadaran akan fungsi negara untuk melindungi individu. ${ }^{9}$

Bassam Tibi beranggapan bahwa HAM adalah hak-hak individu yang lahir dari pemikiran Eropa modern mengenai hukum alam (natural law). Negara Eropa mengangkat hak-hak tersebut sebagai standar institusi hukum. Semenjak itulah Deklarasi Universal mengenai Hak-hak Asasi Manusia (DUHAM) PBB pada tahun 1948 berasal, dan HAM menjadi hukum Internasional. ${ }^{10}$

${ }^{9}$ Tholhatul Choir dan Ahwan Fanani, Islam dalam Berbagai Pembacaan Kontemporer (Yogyakarta: Pustaka Pelajar, 2009), 325.

${ }^{10}$ Bassam Tibi, "Islamic Law/Syariah and Human Rights: International Law and International Relation" dalam Tori Lindholm and Kari Vogt (eds.), Islamic Law Reform and Human Rights: Challenges and Rejoinders (Oslo: Nordic Human Rights Publication, 1993), 75. 


\section{2 | Nurinta Muliani Harahap, Amril Maryolo. AR}

Berbicara tentang sudut pandang HAM di Indonesia, sebagian masyarakat menuntut agar LGBT dilegalkan dan di sisi lain mengkritisi atas perilaku ini. Mereka yang pro berdalih dengan landasan hak asasi manusia (HAM) sebagai dasar utamanya. Bahkan Indonesia selaku negara hukum memberikan jaminan jaminan kebebasan berekspresi diatur dalam UUD 1945 amandemen II, yakni pasal 28 E ayat (2) "setiap orang berhak atas kebebasan meyakini kepercayaan, menyatakan pikiran, dan sikap sesuai hati nuraninya. ${ }^{11}$

LGBT menjadi sebuah masalah bersama. Masalah ini muncul karena menjadi perilaku yang berbeda dengan manusia normal pada umumnya yang di mana sebagian masyarakat mengiginkan perbuatan tersebut dilegalkan di negeri ini. Di lain sisi entah menyangkut problem kejiwaan atau problem sosial budaya, atau lainnya. Kita dituntut agar memahaminya dengan seksama dan mencari solusi alternatif dari problem tersebut.

\section{LGBT SUDUT PANDANG AGAMA}

Pandangan al-Qur'an mengenai LGBT bisa dilihat pada cerita Nabi Luth yakni kaum Sodom dan kaum Amoro di negeri Syam dengan ayatnya dalam Q.S. An-Naml: 54-55, yang berbunyi :

Artinya :

54. dan (ingatlah kisah) Luth, ketika Dia berkata kepada kaumnya: "Mengapa kamu mengerjakan perbuatan fahisyah[1101] itu sedang kamu memperlihatkan(nya)?"

55. "Mengapa kamu mendatangi laki-laki untuk (memenuhi) nafsu (mu), bukan (mendatangi) wanita? sebenarnya kamu adalah kaum yang tidak mengetahui (akibat perbuatanmu)".

Melalui kutipan ayat tersebut diceritakan bahwa kaum Nabi Luth melakukan praktek homoseksual dengan melakukan hubungan badan antar sesama. Di dalam al-Qur'an sendiri tidak ada kata yang spesifik mengenai homo, lesbi, gay, biseksual. Namun, al-Qur'an menyebutnya dengan kata "perbuatan".

Dalam kesepakatan ulama (ijma') menyepakati bahwa aktivitas seksual sesama jenis adalah haram. Pengharaman tersebut bersandar dari kaidah ushul fiqh yang mengatakan "daarul mafaasid muqaddamu 'ala jalbi al-

\footnotetext{
11Istiqomah, "Keberadaan Lesbian, Gay, Biseksual dan Transgender (LGBT) di Indonesia Melalui Cerminan Sosial dan Budaya dalam Perspektif Hukum dan HAM" Jurnal Kajian Ilmiah.,Vol. 17, No. 1 (Januari 2017), 73.
} 
mashalih" (menghindarkan keburukan didahulukan atas mendatangkan maslahat). ${ }^{12}$

Literatur Islam klasikpun menceritakan bahwa Abu Nuwas seorang penyair yang menggemari anak lelaki dan anggur, naskah syairnya menjadi cemoohan orang-orang tetapi tidak sampai kepada taraf menfitnah Abu Nuwas. Begitupun dengan Al-Ghazali seorang ulama mistik pernah menyusun syair untuk kekasih laki-lakinya yang masih berusia muda. Akan tetapi AlGhazali menolak untuk dikatakan homo. ${ }^{13}$ Dari landasan al-Qur'an, hadis, dan ijma sehingga masalah perilaku seksual sesama jenis dianggap final dikategorikan tidak boleh.

\section{GENEALOGI PEMBENTUKAN IDENTITAS SEKSUAL LESBIAN}

Berbicara mengenai seksualitas dan homoseksualitas, tentu tidak lepas dari adanya peran teori. ${ }^{14}$

1. Teori essensialism, seksualitas itu sendiri dapat diartikan sebagai sebuah bentuk perilaku yang didasari oleh faktor fiologis tubuh. Beberapa meyakini orientasi seskual yang dimiliki seseorang (untuk homoseksual, heteroseksual atau biseksual) tersebut merupakan bawaan dari lahir (gen) yang tidak dapat diubah-ubah lagi, sehingga mereka tinggal menjalani saja. Pandangan itu biasa disebut dengan teori esensialisme (essensialism), bahwa hal yang menyebabkan munculnya perilaku seksual sejenis dikarenakan memang individu tersebut memiliki gen yang berbeda dengan yang lainnya, yang mempengaruhi orientasi seksualnya. Teori ini sangat disukai oleh para aktivis advokasi, dan HAM dan bagi kaum lesbian sendiri, serta keluarganya. Mereka menganggap lesbian tersebut bukanlah salah mereka, atau orang yang tidak mendidiknya dengan benar.

2. Teori konstruksi sosial, eksplorasi dari pemikiran Alimi dalam bukunya yang mengkonstruk gagasan bahwa menjadi heteroseksual atau homoseksual bukanlah kodrat, melainkan bentukan sosial. ${ }^{15}$ Tentu saja pandangan ini bila tidak dipahami secara menyeluruh, bisa mejadi

12Masthuriyah Sa'dan, "LGBT Dalam Perpektif Agama dan HAM", Jurnal Nizham Vol. 05, No. 1 (Januari-Juni 2016), 22.

${ }^{13}$ Colin Spencer, Sejarah Homoseksualitas: Dari Zaman Kuno Hingga Sekarang, terj, Ninik Rochani Sjams,(Yogyakarta: Kreasi Wacana, 2004), 111.

${ }^{14}$ Kulkarni, Claudette, Lesbians and Lesbiansm, (London: Routledge, 1997), 68.

${ }^{15}$ Alimi, Moh. Yasir, Dekonstruksi Seksualitas Poskolonial: Dari wacana Bangsa Hingga Wacana Agama, (Yogyakarta: LkiS, 2004), 9. 
halangan bagi para pejuang HAM yang mendasarkan argumennya pada kealamiahan seksualitas. Pendekatan ini tidak mengasumsikan bahwa seksualitas bisa seperti kerudung yang bisa dipilih atau bisa dipakai dan dilepas bila diinginkan.

3. Teori interactionists atau synthesizers sebagai bentuk perpaduan antara esensialisme dan konstruksi sosial. Teori ini mengadopsi beberapa perspektif pluralistic dalam mentrasnformasikan dua teori yang menjadi perdebatan.

Pengembangan identitas lesbian yang telah digunakan dalam literature yaitu:

Model Cass. Pengembangan model ini terdiri dari enam tahap yaitu:

a. Kebingungan identitas. Tahap ini individu merasa mempertanyakan tentang dirinya yang homoseksual. Dirinya diliputi keraguan apakah dirinya homo atau hetero? Pada tahap ini individu mencari informasi lebih jauh tentang homoseksual itu. Karena perasaannya bertentangan dengan identitas yang dibayangkannya sebelumnya. Dia akan mengalami kebingungan dan keresahan. Apabila dia mulai menerima perasaan baru ini, secara sembunyi-sembunyi dia mungkin mencari informasi. Kalau dia menolak atau menentang homoseksualitasnya, identitas yang negative atau penuh benci diri dapat mulai berkembang.

b. Tahap perbandingan identitas. Tahap ini individu mempertimbangkan keadaan dirinya dan penting juga untuk memiliki citra positif sebagai orang lesbian, sehingga ketika individu berada pada tahap ini ia akan menggunakan atribut positif sebagai lesbian, individu ini menyadari perbedaan Antara dirinya dan orang lain. Dia akan merasa terkucil dari orang-orang lain dan punya perasaan takut tidak merupakan bagian masyarakat, keluarga, atau sahabat. Karena lesbian acapkali dipersamakan dengan seks yang menyimpang,

c. Tahap toleransi identitas. Individu mulai melakukan kontak dengan individu lesbian lainnya. Berdasarkan kontak ini, baik asosiasi positif dan negative dari bentuk identitas lesbian. Jika kontak ini adalah negative, maka menurut Cass individu lebih mungkin untuk membentuk persepsi negative tentang dirinya sendiri menjadi lesbian dan menghambat perilaku itu. Jika ia memiliki kontak positif, maka komitmen untuk identitas lesbian meningkat.

d. Penerimaan identitas. Pada tahap ini ditandai dengan sikap menerima identitas lesbian, bukan hanya menoleransi akan keadaan hubungan dengan individu lesbian lainnya menjadi lebih sering sebagai bentuk eksistensi dirinya dalam jaringan sosial dan persahabatan antar lesbian. 
e. Tahap kebanggaan identitas. Pada tahapan ini individu menjadi lebih berkomitmen untuk menjadi lebih berkomitmen untuk menjadi seorang lesbian dan menyadari akan stigma masyarakat luas tentang kaum homoseksual. Pada tahap ini juga individu mulai melakukan perlawanan dari stigma masyarakat. Berbeda dengan tahap-tahap awal, ketika individu ini lebih cenderung untuk menyerah pada stigmastigma yang dilekatkan pada dirinya oleh masyarakat. Bentuk perlawanan ataupun penolakan ini baisanya dalam bentuk pergaulan yang khususnya bagi kelompok-kelompok lesbian.

\section{KONSELING MULTIKULTURAL : SOLUSI PREVENTIF BAGI PELAKU BULLYING}

Dalam kasus bullying pada lesbian, penulis memaparkan solusi yang menurut penulis bisa digunakan dalam menetralisir bullying pada lesbian. Solusi yang dapat digunakan ialah melakukan bimbingan dan konseling di sekolah dan masyarakat menggunakan konseling multicultural. Menurut penulis agar bullying pada lesbian tidak merajalela dan mendapat perlakuan adil, maka yang perlu dilakukan adalah mengubah mindset masyarakat tentang lesbian. Karena menurut teori essensialism pasangan sejenis dikarenakan karena gen dan bukan karena kemauan mereka. Menurut pemahaman penulis, LGBT tidaklah termasuk perilaku patalogi, yang menjadi masalah ialah mukhannas ialah perempuan yang berperilaku seperti laki-laki dan sebaliknya laki-laki yang berperilaku seperti perempuan. Mungkin yang menjadi masalah di kalangan masyarakat ialah pekerjaan LGBT misalnya prostitusi yang membuat masyarakat resah. ${ }^{16}$ Namun, perlu diingat hal membuat mereka seperti itu ialah masyarakat itu sendiri. Sekolah maupun dimasyarakat tidak memberikan mereka kesempatan untuk menggali keterampilan mereka yang akhirnya LGBT lari kepekerjaan seperti itu.

Maka sangat dibutuhkan penyelesaian dari para pemegang kebijakan dan konselor maupun keluarga untuk mengatasi hal ini, agar potensi para LGBT dapat disalurkan, pada perkerjaan yang layak dan tidak dianggap sebelah mata oleh masyarakat. Agar pandangan masyarakat terhadap khususnya lesbian tidak didiskriminasi maka secara teori dapat di selesaikan dengan melakukan konseling multikultural di lembaga pendidikan dan di masyarakat. Alasan penulis memberikan solusi konseling multikultural ialah sebagai berikut:

${ }^{16}$ Sekar Ayu Ariyani, Penjelasan dari buku Waria, hari Jumat pukul 11:00 Wib. Di Ruangan 303. 


\section{6 | Nurinta Muliani Harahap, Amril Maryolo. AR}

1. Masyarakat memiliki perbedaan agama, etnis, Bahasa daerah, geografis, dan budaya.

2. Kemajemukan masyarakat bisa dilihat dari pendidikan, ekonomi, dan tingkat sosial budayanya.

3. Konseling multikultural adalah upaya memahami dan memiliki kepekaan terhadap individu dari segi apapun terkhusus dari segi kepribadiannya yaitu seksualnya. Dan lebih mengedepankan tatanan sosial yang care (peduli).

Locke (dalam Brown et al, 1988) mendefinisikan konseling Multikultural sebagai bidang praktik yang (1) menekankan pentingnya dan keunikan (kekhasan) individu, (2) mengaku bahwa konselor membawa nilai-nilai pribadi yang berasal dari lingkungan kebudayaannya ke dalam setting konseling, dan (3) selanjutnya mengakui bahwa klien-klien yang berasal dari kelompok ras dan suku minoritas membawa nilai-nilai dan sikap yang mencerminkan latar belakang budaya mereka. Dengan perkataan lain, ada tiga hal pokok yang menyangkut pengertian konseling multikultural. Pertama, individu itu penting dan has (unik), Kedua, waktu menjalankan konseling, konselor membawa nilai-nilai yang berasal dari lingkungan budayanya. Ketiga, klien dari kelompok minoritas etnik dan ras datang menemui konselor membawa seperangkat nilai dan sikap yang mencerminkan latar belakang budayanya. Secara singkat dapat dikemukakan bahwa konseling multikultural merupakan proses interaksi antara konselor dan konseli dengan latar belakang budaya yang berbeda sehingga diperlukan pemahaman terhadap konsep dan budaya lain terutama bagi konselor agar dapat memberikan bantuan secara efektif sesuai perspektif budaya konseling. Oleh karena itu konseling multikultural dapat dilihat secara umum sebagai konseling "dimana konselor dan kliennya berbeda".

Isu-isu dalam Konseling Multikultural. Menurut Gladding ada beberapa isu-isu dalam konseling multikultural:

1. Pengetahuan akan cara pandang klien yang berbeda budaya

2. Kepekaan terhadap cara pandang pribadi seseorang dan bagaimana seseorang merupakan hasil dari sebuah pengkondisian budaya

3. Keahlian yang diperlukan bekerja dengan klien yang berbeda budaya.

4. Konselor yang memiliki pengetahuan dan kesadaran tentang sistem budaya biasanya akan lebih ahli dalam membantu anggota dari kelompok budaya tertentu. Sehingga konselor tersebut berbagi cara pandang yang sama dengan klien, membuat intervensi yang lebih baik dan pantas, namun tetap mempertahankan integritas personal.

5. Perkembangan dan pengguanaan teori-teori konseling hal ini untuk mengatasi bias kultur. 
Itulah beberapa isu yang berkembang dalam konseling multikultural yang mana hal ini menjadi hal yang sangat perlu diperhatikan agar permasalahan-permasalah yang terjadi bisa diatasi dengan pemahaman yang lebih baik dengan terus berlatih dan menambah wawasan agar menjadi tenaga konselor yang profesional. 17

Namun yang menjadi fokus dalam penulisan ini ialah bimbingan dan konseling lebih diarahkan kepada masyarakat agar diskriminasi serta bullying tidak terjadi kepada lesbian dan dapat menerima mereka serta tidak memandang mereka sebagai kelompok minoritas dan dapat diterima di lembaga-lembaga. Bimbingan dan konseling multicultural dapat diterapkan sebagai berikut:

\section{a. Konseling Multikultural di Sekolah}

Untuk dapat mewujudkan keadilan sosial dan tidak menindas kelompok minoritas serta mengembangkan budaya toleransi bisa ditempuh melalui pendidikan. Pendidikan merupakan proses penyadaran kritis bagi harkat kemanusian, mencerahkan, dan membebaskan manusia dari segala bentuk ketertindasan. Supaya pendidikan bisa menjadi unit sosial yang membebaskan, maka seharusnya praktikpraktik pendidikan mengacu pada eksistensi manusia itu sendiri dan menawarkan adanya multiepisteme seksualitas. Karena itu, membangun epistemology marginal sebagai episteme alternative sudah tidak bisa ditunda lagi, keberadaannya mutlak diperlukan sebagai syarat terbentuknya negara yang demokrasi.

Supriyatna (2011: 169) mengemukakan tiga pendekatan yang digunakan dalam konseling multikultural, pertama adalah pendekatan universal atau etik yang menekankan pada keterbukaan dan keuniversalan individu maupun kelompok konseli, sehingga implikasinya kebenaran dari suatu budaya juga merupakan kebenaran menurut budaya orang lain. Kedua, pendekatan emik yang menyasar karakteristik khas budaya masing-masing, sehingga mengacu pada temuan-temuan yang berbeda dari beberapa budaya yang berbeda. Implikasinya kebenaran dalam suatu budaya belum tentu kebenaran menurut budaya lain. Ketiga pendekatan transkultur atau inklusif. Konselor dalam proses konseling mempunyai keterlibatan yang aktif dan resiprokal, Tidak bersifat pasif sebagai pengamat saja. ${ }^{18}$

Pendidikan memiliki kaitan erat dengan setiap perubahan sosial, baik berupa dinamika perkembangan individu maupun proses sosial dalam skala yang lebih luas. Secara tegas, Muhammad Abduh, sebagaimana dikutip Azra, mengatakan bahwa pendidikan merupakan alat yang ampuh untuk melakukan perubahan. ${ }^{19}$

${ }^{17}$ Samuel T Gladding , Konseling profesi yang menyeluruh, (Jakarta: Indeks, 2012), 103.

${ }^{18}$ Supriyatna, M., Bimbingan dan Konseling Berbasis Kompetensi. (Jakarta: PT. Raja Grafindo Persada, 2011), 169.

${ }^{19}$ Ngainun Naim \& Achmad Sauqi, Pendidikan Multikultural Konsep dan Aplikasi, (Yogyakarta: Ar-Ruzz Media, 2011), 35. 


\section{8 | Nurinta Muliani Harahap, Amril Maryolo. AR}

Konselor profesional sekolah menghargai dan memahami perbedaan di sekolah pada beberapa daerah seperti, ras, etnik, gender, usia, kekhasan, bahasa, orientasi seksual dan status ekonomi sosial. Konselor profesional sekolah bekerja untuk meyakinkan bahwa siswa dengan latar belakang yang berbeda-beda memiliki akses untuk kebutuhan dan peluang layanan (ASCA, 1999).

Berdasarkan uraian di atas, hal mendasar yang seharusnya disadari bersama adalah pendidikan yang seragam dan tidak menghargai terhadap pluralitas justru banyak membawa implikasi negatif. Penyeragaman bukan saja mematikan kreativitas, tetapi lebih jauh juga dapat melahirkan sikap dan cara pandang yang tidak toleran. Oleh karena itu, membangun pendidikan yang berparadigma pluralitas-multikultural merupakan kebutuhan yang tidak bisa ditunda lagi. Dengan paradigm semacam ini, pendidikan diharapkan akan melahirkan anak didik yang memiliki cakrawala pandangan luas, menghargai perbedaan, pebuh toleransi, dan penghargaan terhadap segala bentuk perbedaan. Maka yang perlu dilakukan oleh seorang konselor dalam konseling multicultural di sekolah ialah menerapkan kurikulum yang berbasis multicultural yang dapat memberi pemahaman kepada siswa tentang perbedaan dan keragaman yang membuat siswa saling menghargai, menghormati, dan toleran. Dalam hal ini lebih kepada pencegahan (preventif). b. Konseling Multikultural di Masyarakat

Pemerintah juga harus memperbaiki regulasi dan sejumlah kebijakan yang ramah serta peduli terhadap kaum LGBT sehingga kaum LGBT bisa merasakan hak-hak mereka di berbagai sendi kehidupan. Regulasi dan kebijakan yang dibuat oleh pemerintah harus juga didukung oleh masyarakat sehingga tidak lagi terjadi stigma, diskriminasi, dan kekerasan pada kaum LGBT. Masyarakat harus diberikan sosialisasi dan menambah pengetahuan mereka tentang kaum LGBT dan hak asasi mereka yang layak mereka terima. Apapun yang terjadi, kaum LGBT juga merupakan manusia yang layak untuk dihormati dan dihargai. Ketika kaum LGBT diperhatikan hak-hak hidup mereka dan mendapatkan keadilan sosial maka mereka akan menjadi sejahtera secara fisik, psikis, dan psikologis.

Kebijkan multikultural yang diterapkan pemerintah bisa meliputi:

1) Pengakuan akan kewarganegaraan jamak (multiple citizenship).

2) Dukungan pemerintah atas surat kabar, acara televise dan siaran radio dalam Bahasa-bahasa yang dipakai oleh kaum minoritas

3) Dukungan atas festival, hari libur dan perayaan-perayaan public lainnya yang diselengarakan oleh kelompok minoritas.

4) Membuat program-program yang membuka akses dan kemudahan untuk kaum minoritas merepresentasikan diri mereka ke dalam politik, pendidikan, dan dunia kerja. 
5) Mendukung musik dan karya-karya seni yang dibuat dan dipertunjukkan oleh budaya minoritas.

\section{PENUTUP}

Perilaku bullying sering dihadapi oleh mereka yang terindikasi atau berperilaku LGBT tekhusus pada perilaku lesbian. LGBT ini dianggap oleh sebagian masyarakat sebagai pendosa, penyimpangan seksual dan kelainan seksual. kelompok ini mengalami diskriminasi dan stigma di ruang publik.

Muncul wacana pro-kontra dalam memandang lesbian. Ada yang melihatnya sebagai pilihan atas hak hidup. Namun ada juga yang melihatnya sebagai perilaku yang deviant dan tidak bermoral. Beragam pandangan mengenai status LGBT dalam pandangan agama, LGBT merupakan sifat yang tak terpuji dan dilabeli sebagai perilaku haram. Sedangkan, pandangan HAM merupakan hak atas kehidupan dan pilihan mereka untuk berperilaku. Meskipun secara umum dalam aspek hukum di Indonesia LGBT masih menjadi hal yang dilarang karena merupakan perilaku yang menyimpang dan menyalahi kodrat.

Dalam hal menetralisir bullying pada lesbian, hal yang tepat dilakukan yaitu konseling multikultural. Konseling multikultural adalah sikap menghargai perbedaaan etnik, ras, agama, dan perilaku kelompok ras dan suku minoritas membawa nilai-nilai dan sikap yang mencerminkan latar belakang budaya mereka. Konseling multikultural untuk mencegah bullying kepada para lesbian harus dimulai oleh pemangku kebijakan dan para konselor di institusi pendidikan dan masyarakat. Peran konselor, keluarga dan pembuat kebijakan dibutuhkan untuk mengatasi pandangan stigmasisasi terhadap para LGBT khususnya lesbian.

\section{DAFTAR PUSTAKA}

Alimi, Moh. Yasir. Dekonstruksi Seksualitas Poskolonial: Dari wacana Bangsa Hingga Wacana Agama, Yogyakarta: LkiS, 2004.

Choir, Tholhatul dan Ahwan Fanani. Islam dalam Berbagai Pembacaan Kontemporer. Yogyakarta: Pustaka Pelajar, 2009.

Gerda, Akbar. "Mental Imagery Mengenai Lingkungan Sosial Baru Pada Korban Bullying", Journal: Flisip-Ummul, Tahun 2013.

Gladding , Samuel T. Konseling profesi yang menyeluruh, Jakarta: Indeks, 2012 Istiqomah."Keberadaan Lesbian, Gay, Biseksual dan Transgender (LGBT) di Indonesia Melalui Cerminan Sosial dan Budaya dalam Perspektif Hukum dan HAM" Jurnal Kajian Ilmiah.,Vol. 17, No. 1 (Januari 2017).

Jackson, dkk. Pengantar Teori-teori Feminis Kontemporer. Yogyakarta: Jalansutra, 2009. 
Jeffreys, Sheila, The Lesbian Heresy, Melbourn: Spinifex Press, 1993.

Kiartono, Kartini. Psikologi Wanita jilid I, Bandung: Alumni 1977.

Kulkarni, Claudette, Lesbians and Lesbiansm. London: Routledge, 1997.

Naim, Ngainun dan Achmad Sauqi. Pendidikan Multikultural Konsep dan Aplikasi, Yogyakarta: Ar-Ruzz Media, 2011.

Ophilia Papilaya, Jeanete. "Lesbian, Gay, Biseksual, Transgender (LGBT) dan Keadilan Sosial”, Jurnal Humaniora Yayasan Bina Dharma,Vol. III, No. 1, 2016.

Sa'abah, Marzuki Umar. Prilaku Seks Menyimpang Dan Seksualitas Kontemporer Umat Islam. Yogyakarta: UII press, 2001

Sa'dan, Masthuriyah. "LGBT Dalam Perpektif Agama dan HAM", Jurnal Nizham Vol. 05, No. 1 (Januari-Juni 2016).

Sinyo, Anakku Bertanya Tentang LGBT, Jakarta: PT Elex Media Komputindo, 2014.

Spencer, Colin. Sejarah Homoseksualitas: Dari Zaman Kuno Hingga Sekarang, terj, Ninik Rochani Sjams. Yogyakarta: Kreasi Wacana, 2004.

Supriyatna, M., Bimbingan dan Konseling Berbasis Kompetensi. Jakarta: PT. Raja Grafindo Persada, 2011.

Tibi, Bassam. "Islamic Law/Syariah and Human Rights: International Law and International Relation" dalam Tori Lindholm and Kari Vogt (eds.), Islamic Law Reform and Human Rights: Challenges and Rejoinders. Oslo: Nordic Human Rights Publication, 1993. 